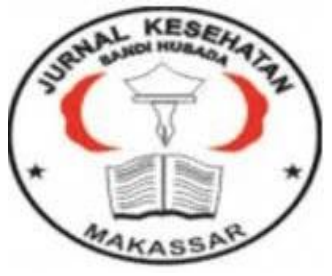

Jurnal Ilmiah Kesehatan Sandi Husada

hhttps://akper-sandikarsa.e-journal.id/JIKSH

Volume 9, Nomor 2, Desember 2020, pp 860-864

p-ISSN: 2354-6093 dan e-ISSN: 2654-4563

DOI: $10.35816 /$ jiskh.v10i2.426

\title{
Efek Kurkumin Pada Kunyit (Curcuma longa) Sebagai Pengobatan Kanker Lambung
}

Effect of Curcumin on Turmeric (Curcuma longa) as a Tretment for Stomach Cancer

Firantika Dias Puteri

Fakultas Kedokteran, Universitas Lampung

\begin{tabular}{l}
\hline \multicolumn{1}{c}{ Artikel info } \\
\hline Artikel history: \\
Received; Agustus 2020 \\
Revised;September 2020 \\
Accepted;September2020
\end{tabular}

\begin{abstract}
Abstrak
Latar Belakang: Kanker atau keganasan merupakan sekelompok penyakit yang ditandai dengan pertumbuhan yang tidak terkendali dan penyebaran sel-sel abnormal. Salah satu kanker yang masih menjadi masalah di dunia adalah kanker lambung. Kanker lambung merupakan salah satu penyumbang utama kematian yang tinggi di dunia, terutama pada kalangan pria di usia tua. Terdapat beberapa metode pengobatan yang biasa dilakukan, seperti pembedahan, radiasi dan kemoterapi. Pemilihan metode tersebut tergantung pada jenis dan stadium perkembangan tumor. Kemoterapi merupakan salah metode pengobatan pilihan, namun tingkat keberhasilan pengobatan ini terbatas karena adanya kemoresistensi. Tanaman herbal merupakan salah satu senyawa aktif yang dipercaya menjadi salah satu alternatif sebagai antikanker karena memiliki efek samping minimal. Salah satu tanaman yang dapat dimanfaatkan adalah kunyit (Curcuma longaI). Tujuan: mengetahui lebih lanjut tentang manfaat kunyit sebagai pengobatan kanker lambung. Metode: Metode yang digunakan oleh penulis adalah studi literatur dari berbagai jurnal nasional maupun internasional. Metode ini digunakan dengan tujuan menambah pengetahuan dan pemahaman mengenai topik yang dibahas dengan menyajikan materi yang telah diterbitkan dengan meringkas materi yang telah diterbitkan serta memberikan informasi fakta atau analisis baru dari tinjauan literatur yang relevan kemudian membandingkan hasil tersebut dalam artikel. Hasil: Senyawa kurkumin dari tanaman Curcuma longa dapat berperan dalam menghambat proliferasi sel kanker, antiinflamasi, penghambatan karsiogenik, immunomodulatory, antiestrogem dan antiangiogenesis. Perannya dalam tumorigenesis juga dimediasi melalui ekspresi gen yang menekan apoptosis, memediasi proliferasi, invasi dan angiogenesis. Kesimpulan:
\end{abstract}




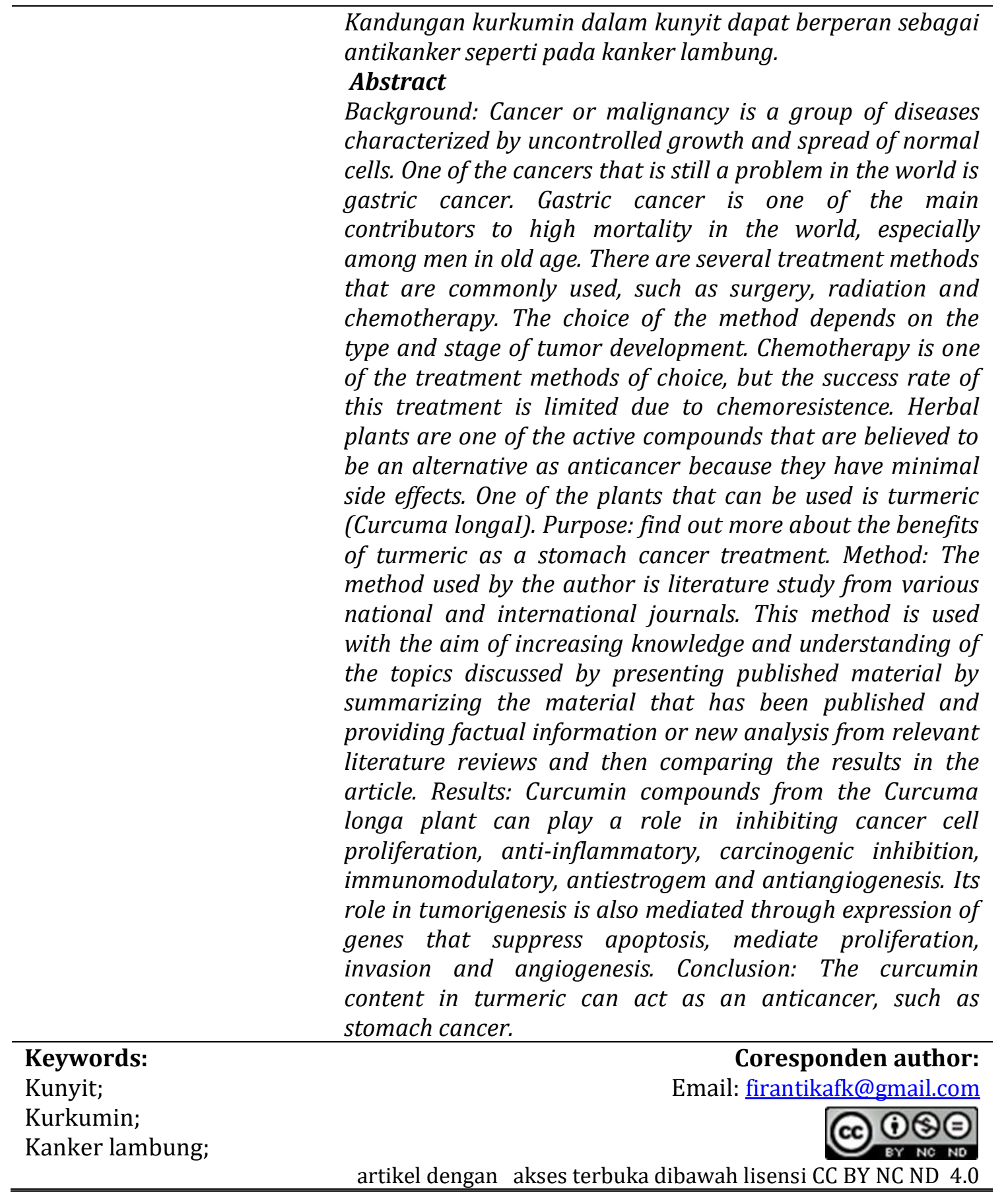

\section{Pendahuluan}

Kanker atau keganasan merupakan sekelompok penyakit yang ditandai dengan pertumbuhan yang tidak terkendali dan penyebaran sel-sel abnormal. Salah satu kanker yang masih menjadi masalah di dunia adalah kanker lambung. Kanker lambung merupakan salah satu penyumbang utama kematian yang tinggi di dunia, terutama pada kalangan pria di usia tua (Rawla, 2019). Berdasarkan data GLOBOCAN 2018, kanker lambung adalah keganasan paling umum ke-5 dan paling mematikan ke-3 dengan jumlah $782.685(8,2 \%)$ kematian (WHO, 2019). Kelangsungan hidup pasien dikaitkan dengan stadium penyakit, dan angka kesembuhan tergantung pada tindakan operatif yang dilakukan. Kurang dari 5\% pasien yang memiliki stadium lanjut dapat bertahan hidup 
kurang dari 5 tahun, dengan hanya 25\% pasien kanker Lambung yang mendapatkan tindakan operatif (Yang, 2011). Terdapat beberapa metode pengobatan yang biasa dilakukan seperti pembedahan, radiasi dan kemoterapi. Pemilihan metode tersebut tergantung pada jenis dan stadium perkembangan tumor (Mutiah, 2015). Kemoterapi merupakan salah metode pengobatan pilihan, namun tingkat keberhasilan pengobatan ini terbatas karena adanya kemoresistensi (Yu, 2011). Pengobatan dengan menggunakan kemoterapi juga dapat menimbulkan berbagai macam efek samping seperti rambut rontok, supresi sumsum tulang, resistensi obat, gangguan gastrointestinal, disfungsi neurologi dan toksisitas jantung (Hosseini, 2015). Tanaman herbal merupakan salah satu senyawa aktif yang dipercaya menjadi salah satu alternatif sebagai antikanker karena memiliki efek samping minimal. Kunyit adalah tanaman rimpang keluarga Zingiberaceae (Jahe). Kunyit banyak digunakan sebagai bumbu, pengawet makanan dan bahan pewarna di India, Cina dan Asia Tenggara. Terlepas dari kegunaannya pada bidang kuliner, kunyit telah digunakan secara luas dalam pengobatan tradisional di seluruh dunia (Verma, 2018).

Bahwa penderita gastritis akan menjadi lebih buruk jika dirinya mengalami stres. Selain stress, masuknya udara lewat mulut ketika mengkonsumsi makanan juga bisa menyebabkan perut semakin kembung dan frekuensi sendawa meningkat (Suprapto, 2020). Kurkumin, sejenis polifenol yang diekstrak dari akar rimpang kunyit (Curcuma longa) dikenal sebagai diferuloylmethane dengan nama IUPAC (1E, 6E) -1,7-bis (4hydroxy-3-methoxyphenyl) -1,6-heptadiene-3,5-dione, memiliki rumus kimia C21H2006 dan berat molekul 368,38 diketahui memiliki banyak manfaat (Giordano, 2019). Beberapa efek farmakologis antara lain, antiinflamasi, antioksidan, antikarsinogenik, antimutagenik, antikoagulan, antifertilitas, antidiabetik, antibakteri, antijamur, antiprotozoa, antivirus, antifibrotik, antivenom, antiulcer, hipotensi dan hipokolesteremik. Bagi ahli ayurveda tradisional, tanaman kunyit merupakan antiseptik alami yang sangat baik, disinfektan, anti-inflamasi, dan analgesik, sementara pada saat yang sama tanaman ini sering digunakan untuk pengobatan saluran pencernaan, memperbaiki flora usus, dan untuk mengobati iritasi kulit (Verma, 2018). Kandungan antioksidan yang tinggi pada curcuminoid dapat digunakan dalam pengobatan penyakit PCOS (Polycystic ovary syndrome)(Fahrumnisa,2019). Manfaat terapeutik kurkumin telah dibuktikan pada berbagai penyakit kronis: peradangan, artritis, sindrom metabolik, penyakit hati, obesitas, penyakit neurodegeneratif, dan yang terpenting pada beberapa jenis kanker (Giordano, 2019).

\section{Metode}

Metode yang digunakan oleh penulis adalah studi literatur dari 18 jurnal nasional maupun internasional. Metode ini digunakan dengan tujuan menambah pengetahuan dan pemahaman mengenai topik yang dibahas dengan menyajikan materi yang telah diterbitkan dengan meringkas materi yang telah diterbitkan serta memberikan informasi fakta atau analisis baru dari tinjauan literatur yang relevan kemudian membandingkan hasil tersebut dalam artikel.

\section{Hasil Dan Pembahasan}

Kanker adalah penyakit yang berhubungan dengan kecepatan pertumbuhan sel abnormal dalam tubuh yang tidak terkendali. Sel tersebut dapat menginvasi jaringan sel disekitarnya dan menyebar ke organ lain atau yang disebut dengan metastasis. Salah satu kanker yang masih menjadi masalah di dunia adalah kanker lambung. Kanker lambung merupakan salah satu penyumbang utama kematian yang tinggi di dunia, terutama pada kalangan pria di usia tua (Rawla, 2019). Terdapat beberapa metode pengobatan yang biasa dilakukan, seperti pembedahan, radiasi dan kemoterapi. Pemilihan metode tersebut 
tergantung pada jenis dan stadium perkembangan tumor (Mutiah, 2015). Sebanyak 27$58 \%$ kanker lambung dapat dideteksi secara awal dengan pengecekan kadar mesothelin, yang diharapkan dapat meningkatkan prognosis yang baik (Al azizah, 2019). Kemoterapi merupakan salah metode pengobatan pilihan, namun tingkat keberhasilan pengobatan ini terbatas karena adanya kemoresistensi (Yu, 2011). Selain itu, kemoterapi juga memiliki banyak efek samping, sehingga diperlukan alternatif lain yang lebih bermanfaat (Sharman, 2014).

Tanaman herbal adalah sebuah pengobatan tradisional yang sering digunakan karena mudah didapatkan dan terjangkau (Septyarani, 2019). Salah satu tanaman herbal yang dapat digunakan sebagai alternatif pengobatan kanker adalah Kunyit (Curcuma longa). Studi efek antikanker senyawa kurkumin dari tanaman Curcuma longa telah banyak dilakukan diantaranya dapat menghambat proliferasi sel kanker, antiinflamasi, immunomodulator, antiestrogen dan antiangiogenesis (Sharma, 2004). Sebuah penelitian melaporkan bahwa kurkumin dan 5-fluorouracil (5-FU) secara sinergis menghambat pertumbuhan sel karsinoma lambung. Beberapa studi kemoprevensi, memperoleh hasil bahwa tikus yang diberi makan kurkumin pada kunyit (2\%-5\%) secara signifikan menghambat tumor lambung. Studi lain juga mengungkapkan efek kurkumin pada kanker lambung. Penurunan signifikan pada forestomach papiloma juga terbukti karena pengobatan dengan menggunakan ekstrak kunyit yang mengandung kurkumin (Anand, 2008). Sifat antiinflamasi dan kandungan antioksida juga memiliki efek gastroprotektor dalam membantu proses penyembuhan tukak lambung (Pratiwi,2020).

Penelitian lain melaporkan efek farmakologi kurkumin sebagai pengobatan kanker lambung. Kurkumin berperan dalam menghambat protein antiapoptosis dari Bcl-2 dan meningkatkan ekspresi p53, Bax, procaspases 3, 8, dan 9. Kurkumin menyebabkan disipasi Potensial Membran Mitokondira (MMP) dan pelepasan sitokrom c ke dalam sitosol sel SGC-7901 yang menimbulkan apoptosis( Xue, 2014). Selain itu kurkumin juga dapat menghambat jalur STAT3 yang merupakan jalur utama karsinogenik. Signifikasi onkogenik dari molekul STAT3 yang teraktivasi terjadi karena efeknya pada berbagai parameter, seperti apoptosis, proliferasi sel, angiogenesis, dan penghindaran sistem kekebalan tubuh. STAT3 secara aktif dan terus menerus telah terlibat dalam induksi resistensi terhadap apoptosis, mungkin melalui ekspresi Bcl-xL dan cyclin D1. Perannya dalam tumorigenesis dimediasi melalui ekspresi gen yang menekan apoptosis, memediasi proliferasi, invasi dan angiogenesis (Abdurrahman, 2019). Efek antikanker dari kurkumin juga disebabkan oleh penekanan proliferasi sel, telah dilaporkan bahwa kurkumin secara signifikan menurunkan ekspresi Cyclin D dan menghambat aktivasi kinase 1 yang diaktifkan p21 (PAK1) sehingga meningkatkan penekanan proliferasi dan invasi sel kanker lambung (Cai, 2009). Selain itu, kurkumin telah dilaporkan bekerja pada cascape-3 (mediator apoptosis) dengan aktivasi dan penghambatan jalur sinyal Akt/mTOR/p70S6 (Shehzad, 2014).

\section{Simpulan Dan Saran}

Kanker adalah penyakit yang berhubungan dengan ketidakterkontrolnya kecepatan pertumbuhan sel abnormal dalam tubuh. Sel tersebut dapat menginvasi jaringan sel disekitarnya dan menyebar ke organ yang lain atau yang disebut dengan metastasis. Senyawa kurkumin dari tanaman Curcuma longa dapat berperan dalam menghambat proliferasi sel kanker, antiinflamasi, penghambatan karsiogenik, immunomodulator, antiestrogen dan antiangiogenesis. Perannya dalam karsinogenesis juga dimediasi melalui ekspresi gen yang menekan apoptosis, memediasi proliferasi, invasi dan angiogenesis. 


\section{Daftar Rujukan}

Abdurrahman, Nabil. 2019. Kurkumin pada Curcuma longa sebagai Tatalaksana Alternatif Kanker. Jurnal Agromedicine. Vol. 6(2): 410-415.

Al azizah, F., N., \& Hanriko, R. 2019. Mesothelin Sebagai Biomarker Deteksi Dini Kanker Pankreas. Jurnal Ilmiah Sandi Husada. Vol. 10(2):143-150.

Anand, Preetha., Sundaram, Chitra., Jhurani, Sonia., et al. 2008. Curcumin and Cancer: An "old-age" disease with an "age-old" solution. Cancer Latters. 267: 133-164.

Cai, X.Z., Wang, J., Li, X.D., et al. 2009. Curcumin Suppresses Proliferation and invasion in Human Gastric Cancer Cell by Dornregulation of PAK1 Activity and Cyclin D1 Expression. Cancer Biol. Ther. Vol. 8: 1360-1368.

Fahrumnisa, A., R. 2019. Ekstrak Kunyit (Curcuma longa) sebagai Tatalaksana Sindrom Polikistik Ovarium. Jurnal Ilmiah Kesehatan Sandi Husada. Vol. 10(2):115-120.

Giordano, A., \& Tommonaro, G. 2019. Curcumin and Cancer. Nutrients. Vol. 11(2376): 1-20. https://doi.org/10.3390/nu11102376

Hosseini, A., Ghorbani, A. 2015. Cancer therapy with phytochemical: evidence form clinical studies. Avicenna J Phytomed. Vol. 5(2): 84-97.

Mutiah, R. 2015. Evidence Based Kurkumin Dari Tanaman Kunyit (Curcuma Longa) Sebagai Terapi Kanker Pada Pengobatan Modern. Jurnal Farma Sains, 1(1): 28-41.

Pratiwi, A., D. 2020. Efek Gastroprotektor Madu Terhadap Penyembuhan Tukak Lambung. Jurnal Ilmiah Kesehatan Sandi Husada. Vol. 11(1):512-516.

Rawla P, Barsouk A. Epidemiology of Gastric Cancer: Global trends, risk factors and prevention. Gastroenterology Review. 2019; 14(1): 26-38.

Septiyarani, E. 2019. Potensi Buah Pare (Momordhica Charantia) Sebagai Agen Pengobatan Ulkus Peptikum. Jurnal Ilmiah Kesehatan Sandi Husada. No. $10(2): 222-225$.

Suprapto, S. (2020). Penerapan Asuhan Keperawatan Pada Gangguan Sistem Pencernaan "Gastritis." Jurnal Ilmiah Kesehatan Sandi Husada, 11 (1 SE-Articles). https://doi.org/10.35816/jiskh.v11i1.211

Sharma, R.A., Euden, S.A., Platton, S.L., et al. 2004. Phase I Clinical Trial of Oral Kurkumin: Biomarkers of Systemic Activity and Compliance. Clinical Cancer Research: An Official Journal of the Cancer Research. 10: 6847-6854.

Shehzas, A., Wahid, F., Lee, Y.S. 2014. Curcumin in cancer chemoprevention: Molecular targets, Pharmacokinetiks, bioavailability, and clinical trials. Arch. Pharm. Vol. 343: 489-499.

Verma, RK., Kumari, P., Maurya, RK., Kumar, V., \& Singh, RK. (2018). Medicinal Properties Of Turmeric (Curcuma longa L.): A Review. International Journal Of Chemical Studies, 6(4): 1354-1357.

WHO. 2019. GLOBOCAN Tersedia di: https://gco.iarc.fr/today/data/factsheets/cancers/7Stomach-fact-sheet.pdf

Xue, X., Yu, J.L., Sun, D.Q., et al. 2014. Curcumin Induces Apoptosis in SGC-7901 Gastric Adenocarcinoma Cells Via Regulation of Mitochondrial Signaling Pathway. Asian Pac. J. Cancer Prev. 15: 3987-3992.

Yang D, Hendifar A, Lenz C, Togawa K, Lenz F, Lurje G, Pohl A, Winder T, Ning Y, Groshen S and Lenz HJ. 2011. Survival of meta- static gastric cancer: Signi cance of age, sex and race/ethnicity. J Gastrointest Oncol Vol. 2: 77-84.

Yu, LL., Wu, J., Dai, N., Yu, H., \& Si., J. 2011. Curcumin Reverses Chemoresistance of Human Gastric Cancer Cells By Downregulating the NF-kB Transcription Factor. Oncology Reports, 26: 1197-1203. https://doi.org/10.3892/or.2011.1410 